\title{
Select document: Exchequer malpractice in late medieval Ireland: a petition from Christopher Fleming, Lord Slane, 1438
}

\section{Introduction}

$\mathrm{P}$ reserved amongst the Chancery masters' exhibits at the National Archives of the U.K., formerly known as the Public Record Office, is a box of documents concerning the Fleming family, Lords Slane, in Ireland. ${ }^{1}$ These papers, dating from the fifteenth and sixteenth centuries, relate primarily to a protracted inheritance dispute between the heirs male and heirs general of Christopher Fleming, Lord Slane, who died in 1458. This case had been brought into the English Chancery because the family were also landowners in Devon and Cornwall, and it had then rumbled on for decades. ${ }^{2}$ Within this box, however, there is also a parchment roll containing a number of entries relating to their Irish lands. The eighth item on this roll is especially interesting. It is a petition dated 1438 from Christopher Fleming, Lord Slane, complaining about irregularities in the Irish Exchequer seventeen years earlier. It is Fleming's petition that forms the subject of this article.

Fleming's complaint was made during a period of acute turmoil, with the area later to be known as the Pale beset by sustained Irish attacks, internal dissension amongst the English nobility in Ireland, and an administration that was continually accused of corruption and extortion. Chronicle sources highlight the extreme pressure being brought to bear on the English-controlled area during the first three decades of the fifteenth century. Significant incursions by the Irish took place in 1404, 1406, 1407, 1411, 1413 and 1414. The 'English' of Meath, normally led by the sheriff, undertook regular raids into Irish-controlled territory. These were often conducted at a high cost. In 1373 it was recorded that the sheriff and William Dalton were killed in a raid against the Cenel Fiachach and Ó Mailshechlainn, while in 1406 the sheriff of Meath led a raid with the Daltons but was heavily

I These documents are to be found in T.N.A. P.R.O., C103/18. I would like to thank Dr Brendan Smith of the University of Bristol for his advice and encouragement during the preparation of this article.

2 In fact, there were still repercussions in the early sixteenth century. Christopher Fleming, Lord Slane, sued Nicholas Dillon and Patrick Bellew: Chancery Proceedings, Christopher Fleming, Lord Slane, plaintiff, Nicholas Dillon and Patrick Bellew, defendants, 1515-17 (T.N.A. P.R.O., C1/407/41-3; C103/18). Christopher Fleming's son, James Fleming, Lord Slane, was also sued in Star Chamber by Robert Dillon and Patrick Bellew: Star Chamber proceedings, Robert Dillon and Patrick Bellew, plaintiffs, James Fleming, Lord Slane, defendant, 1518-19 (T.N.A. P.R.O., STAC 2/15, ff 109-18). 
defeated by Ó Mailshechlainn, the men of Breaghmhuine and the Dillons. Defeat seems to have been a feature of the 'English' defence of Meath. In fact, in 1411 Ua Conchobhair Failge was reported to have captured 160 prisoners, including the sheriff of Meath. Ransoms were said to amount to 1,600 marks - approximately $£ 1,000$. Then, in 1414 , Christopher Fleming was in turn taken prisoner by Ua Conchobhair Failge, and a sizeable ransom extracted for his release. Despite vigorous campaigns against the Irish in $1415,1417,1419,1420,1421,1425$, 1428,1433 and 1434, any successes were short-lived because on each occasion a shortage of funds prevented the administration from exploiting its military advantage. ${ }^{3}$ The administration was suffering a severe financial crisis. Irish revenues had declined steadily throughout the fourteenth century, and the administration was unable to remain solvent without subsidies from England. In 1368-72 Exchequer receipts had totalled $£ 15,53917 s$. $5 d$. However, by 1402 it was reported that the king's lieutenant, Thomas of Lancaster, was

so destitute of money that he has not a penny in the world, nor can he borrow a penny, for all his jewels and his plate, beyond what he must keep of necessity are put and remain in pledge. His soldiers have departed from him, and the people of his household are about to depart ....

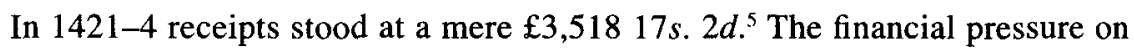
the lordship was primarily due to the determination of Henry $V$ to reduce the dependency on England for supporting its administration and defence. This policy coincided with a more vigorous exploitation of sources of revenue in Ireland. Of those sources of revenue still available to the administration, scutage - a tax paid in lieu of military service - remained the most useful. Unlike England, where its importance had long died out, the frequent need for armies to combat the Irish and to quell internal wrangling amongst the nobility had ensured its survival within the lordship. While the frequency of proclamations of royal service had fallen, the collections of scutage were still being rigorously enforced in the early fifteenth century. ${ }^{6}$

Yet resistance to this feudal demand was equally strong in some quarters. This state of affairs was compounded by the fact that the very individuals upon whom the administration relied to fight the Irish were those from whom they demanded

3 Ann. Conn., s.a. 1373, 1404, 1406, 1407, 1411, 1413, 1414, 1417, 1419, 1421, 1425; A.L.C., s.a. 1404, 1406, 1407, 1411, 1419, 1434; A.U., s.a. 1414, 1418, 1419, 1429, 1433, 1434; Marlborough, Chronicle, s.a. 1413, 1414, 1419, 1421; A.F.M., s.a. 1414, 1419; Reg. Swayne, pp 109-11; Sir James Ware, The antiquities and history of Ireland (London, 1705), pp 64-5, 67-8; Henry Ellis, Original letters illustrative of English history (2nd ser., 2 vols, London, 1827), i, no. 19.

4 A. J. Otway-Ruthven, A history of medieval Ireland (2nd ed., London and New York, 1980), p. 342; F. C. Hingeston (ed.), Royal \& historical letters during the reign of Henry the Fourth, king of England and of France, and lord of Ireland (London, 1860), i, 73-6.

5 S. G. Ellis, 'Ioncaim na hÉireann, 1384-1534' in Studia Hib., xxii-xxiii (1982-3), pp 39-49; Philomena Connolly (ed.), Irish Exchequer payments, 1270-1446 (I.M.C., Dublin, 1998), pp 527-8, 544, 552; James Lydon, The lordship of Ireland in the Middle Ages (Dublin, 1972), pp 243-51; Elizabeth Matthew, 'The financing of the lordship of Ireland under Henry V and Henry VI' in A. J. Pollard (ed.), Property and politics: essays in later medieval English history (Gloucester, 1984), pp 97-115.

6 A. J. Otway-Ruthven, 'Royal service in Ireland' in R.S.A.I. Jn., xcviii (1968), pp 40, 44-5; Robin Frame, Ireland and Britain, 1170-1450 (London, 1998), pp 282-5. 
payment of scutage. The nobility had also seen their own revenues decline drastically. The Fleming lands, located primarily in the north of Meath, had suffered repeated Irish attacks during the late fourteenth and early fifteenth centuries. Indeed, in 1371 their lands at Newcastle, Drym, Lowaneston, Kelleyeston, Brystelaneston, Russagh, Corekernyeston, Monyeston, Balyrath and Clonpertan had been described as waste and worth nothing. It was presumably in response to repeated Irish incursions, along with a desire to display their prominence within the Marcher region, that they had built a new castle at Slane to replace an earlier motte-and-bailey construction. ${ }^{7}$ Christopher Fleming's grievance of 1438 was a clear reflection of simmering magnate resentment. His complaint centred on corruption in the Exchequer in 1421 and the exaction of feudal dues. The Flemings had already engaged in a feud with the Exchequer at the beginning of the century. In June 1401 a commission had been appointed to arrest Thomas Fleming, Lord Slane, his wife Elizabeth, and his son Christopher Fleming for unspecified crimes. In October 1401 Christopher Fleming had been pardoned for ambushing at Rathfaygh the chief baron of the Exchequer, Richard Rede, and for other seditious activities. This apparent bad feeling had not gone away. The Irish memoranda rolls record that Thomas Fleming had been fined $41 s .8 d$. for arrears of payments of royal service between 1406 and 1409 , and his lands distrained. In 1421 he was accused of absenting himself from Ireland without royal licence, although his attorney claimed that he had provided sufficient men for the defence of his lands. ${ }^{8}$

Significantly, Christopher Fleming's complaint centred on the unjust exaction of feudal dues by the Irish Exchequer in the same year. Fleming alleged that William Tynbegh, under-treasurer of the Irish Exchequer, had directed his clerk, John Coryngham, to make an entry in the White Book of the Exchequer altering the terms under which the manor of Slane was held. Slane was the caput of the Fleming family. Fleming claimed the manor was held in fee tail as of the manor of Duleek but that Tynbegh had altered it to Thomas Flemmyng Baro de Slane pro Slane que tenetur de domino Rege per septem servicia, which meant it was held directly from the king by royal service, and which, he argued, rendered him directly liable to the Crown for scutage payments of $£ 14$. A copy for the royal service of the county of Meath extracted from the pipe roll of 1429-30 contained the same information about the tenurial status of Slane. According to the valuations provided in the inquisition post mortem, held in 1459, Fleming's Irish possessions were worth just $£ 282 s$. per annum. A demand of $£ 14$ was approximately half his annual Irish income and, as such, something to be resisted. ${ }^{9}$

7 Terence Barry, 'Defence and settlements in late medieval Ireland' in Terence Barry, Robin Frame and Katharine Simms (eds), Colony and frontier in late medieval Ireland: essays presented to J. F. Lydon (London, 1995), p. 221; Matthew Seaver, 'Practice, spaces and places: an archaeology of boroughs as manorial centres in the barony of Slane' in James Lyttleton and Tadhg O'Keefe (eds), The manor in medieval and early modern Ireland (Dublin, 2005), pp 81-3.

8 S. G. Ellis, 'Taxation and defence in late medieval Ireland: the survival of scutage' in R.S.A.I. Jn., cvii (1977), pp 5, 8, 15, 17; G. E. C., Peerage, xii, pt i, pp 5-6; Rot. pat. Hib., i, pp 160, 197; Cal. pat. rolls, 1399-1401, p. 519; Record Commission calendar of memoranda rolls, 8-10, Henry $V$, pp 198-9, 228-32, 293.

9 The manor of Slane ( $£ 10$ per annum), the manor of Newcastle ( 5 marks per annum), the manor of Culmullin ( $£ 10$ per annum) and a rent of 7 marks from the town of Dundalk: 
In fact, there appeared to be some justification to Christopher Fleming's claim over the precise tenurial status of Slane. The 1371 inquisition post mortem of his grandfather, Simon Fleming, stated that the barony was held in fee from Bartholomew de Burghersh as of his manor of Duleek, which was in turn held from the king in chief by knight service of 21 marks of royal service ( $£ 14)$ when a scutage was current. The barony of Slane had originally formed part of the lands of Theobald de Verdon, who died in 1316. The de Verdon inheritance had finally been partitioned in 1332 between his widow, Elizabeth de Burgh, and his three daughters. The partition document, as recorded in a later seventeenth-century transcription of a fourteenth-century inspeximus, stated that each co-parcener was assigned a fourth part of the wardships, marriages and escheats of the original barony, defined as parishes rather than fees. Furthermore, the barony was clearly identified as being held of the manor of Duleek, and no reference to knight service was made in this document. ${ }^{10}$

Further confusion had emerged after Bartholomew de Burghersh, son and heir of the second de Verdon daughter, had alienated with the king's licence his manor of Duleek to Peter Houth and Hugh Portys, chaplains, at Easter 1369. They had then enfeoffed Robert Wakeman, Richard Laweles, William Warwyk, Richard Eustace and Gilbert Wryght, but without the king's licence. However, because de Burghersh had contravened the 1368 ordinance ordering all who held lands in Ireland to go there themselves for their defence on pain of forfeiture, the manor of Duleek had been seized by the Crown. The inquisition post mortem went on to say that the lordship of the manor of Slane had been seized because Fleming had not attorned to the chaplains or, in fact, the feoffees, as stated earlier in the inquisition. He was required by law to do this in order to demonstrate his agreement to hold his lands from them. Technically, at the time of the forfeiture, the manor of Slane was held from the king, and his heir, Thomas, was a royal ward."

While it would be fair to suggest that Slane was not held directly from the Crown, the de Verdon manor of Duleek was liable for $£ 14$ when a scutage was current. What it is not absolutely certain is how this liability was subsequently shared out amongst the heirs. Ten years after the partition of the de Verdon inheritance, in a document recording the collection of royal service between 1341 and $1343, £ 14$ had been paid 'for the Barony of Slane' by Matilda, wife of Baldwin Fleming, 'in quittance of the heirs of the manor of Duleek'. This would seem to suggest that the liability had ended up with the Flemings alone. It is conceivable that by 1438 there was genuine uncertainty over the status of Slane. In 1430-1 it was reported that the records of the Exchequer, Chancery and both benches

see H. F. Berry (ed.), Statute rolls of the parliament of Ireland, reign of King Henry the Sixth (H.M.S.O., Dublin, 1910), p. 611; extracts from the Pipe roll, 10 Hen. VI (T.C.D., MS 569, f. 47).

10 Otway-Ruthven thought that scutage due from the barony was probably assigned to Elizabeth de Burgh. The partition document (British Library, Cottonian charter ii, 24) is reproduced in A. J. Otway-Ruthven, 'The partition of the De Verdon lands in Ireland in 1332' in R.I.A. Proc., lxvi (1968), pp 421-37. I am grateful to Dr Stephen O'Connor of the National Archives, Kew for his views on the precise meaning of the Latin contained in this document.

1 Cal. pat. rolls, $1370-4$, p. 247. It was not uncommon for increased scutage payments to be demanded from the lands of sub-tenants of lands held in royal custody: Ellis, 'Taxation \& defence', p. 13. 
stored at Dublin Castle were in very poor condition. ${ }^{12}$ Perhaps nobody really knew anymore, and ambiguity over the status of Slane, the sum that should be paid for royal service and by whom it should be paid had arisen because of the imprecise settlement of royal service in the 1332 partition document, the seizure of Slane into royal hands as a consequence of de Burghersh's forfeiture in 1369, and because Simon Fleming's other lands had been taken into royal hands during the minority of his son, Thomas, who also held land by knight service from other royal wards. ${ }^{13}$

Fleming's petition came at a time when the political climate in the Pale was deteriorating. Tensions were running high, and it can be no coincidence that at exactly the same time that Thomas Fleming was being targeted by Tynbegh, complaints were made in the Irish parliament of 1421 about corruption in the Irish Exchequer and the extortionate practices of the king's lieutenant, Sir John Talbot. Talbot's wife was also one of the De Verdon heirs, which perhaps served to increase Fleming's sensitivity to an attack on his tenurial status. Talbot's collectors aroused significant unrest. At the local level, there was active resistance. In one incident, when Talbot's collectors arrived at the door of John Neville, baron of Roscarlon, his servants retaliated by attacking the deputy-steward of the liberty of Wexford, Talbot's lordship. Moreover, from about 1418 onwards, a major feud had been developing between James Butler, the 'white' earl of Ormond, and Talbot. In that year, Ormond's father-in-law, the earl of Kildare, and Sir Christopher Preston were both arrested and briefly imprisoned in the castle of Trim for supposedly conspiring against the lieutenant's deputy and brother, Sir Thomas Talbot. The arrests took place at Slane, although there is no indication that Thomas Fleming, Lord Slane, was involved with the conspirators. Fleming's second wife, Katharine Butler, was Ormond's daughter, yet there is little evidence of close political ties, and Thomas Fleming was not targeted by the lieutenant's administration over this event. ${ }^{14}$ Talbot was king's lieutenant from 1414-19. Although he only enjoyed two further appointments - in 1425 and 1445-7 - significant animosity towards him and his kinsmen amongst the English nobility in Ireland persisted throughout the 1420 s and $1430 \mathrm{~s}^{15}$ Talbot's lieutenancy came to an end in 1420 , yet the machinery of government continued to be staffed by some of his clients. William Tynbegh and John Coryngham had both worked with the Talbots. In November 1417, for example, they were justices of oyer and terminer in Louth, along with the lieutenant's deputy, Sir Thomas Talbot. ${ }^{16}$

The timing of the false entry made in the White Book of the Exchequer by

12 Connolly (ed.), Irish Exchequer payments, 1270-1446, pp 568-9; Exchequer, accounts various, counter roll of receipts of services, 15-16 Edw. III (T.N.A. P.R.O., E 101/241/4).

13 In fact, a writ sent to the escheator of Ireland stated that on his death, Simon Fleming held lands by knight service from Edmund Mortimer, earl of March, a minor in the king's wardship: see papers relating to the Fleming barons of Slane, including abstracts of titles to property in Ireland and England (T.N.A. P.R.O., C103/18); Inquisition post mortem of Simon Fleming, baron of Slane (T.N.A. P.R.O., C135/218/27).

14 H. G. Richardson, 'The Preston exemplification of the Modus tenendi parliamentorum' in I.H.S., iii (1942-3), pp 187-92; A. J. Otway-Ruthven, 'The background to the arrest of Sir Christopher Preston in 1418' in Anal. Hib., xxix-xxx (1980-2), pp 73-94; Rot. pat. Hib., i, 219.

15 R. A. Griffiths, The reign of King Henry VI (Stroud, 1998), p. 413.

16 Dowdall deeds, no. 400. 
Tynbegh against Thomas Fleming, Lord Slane, lends weight to the claims of corruption being made in the Irish parliament. For the Flemings, though, this had wider significance. For the lieutenant's administration to be able to assert tenurial control over the principal Fleming possession was a direct challenge to their position amongst the English nobility in Ireland. They had only recently come into possession of the barony of Slane and established themselves amongst the Irish parliamentary peerage. This made them particularly sensitive about their ranking. Simon Fleming, Lord Slane, when called to parliament in 1370, sat below Robert Preston, Lord Gormanston. Similarly, the Calendar of the Gormanston register records instances when they were sitting above Lord Slane. This dispute over precedence rumbled on for a further ninety years. It was not until 1462 that it was settled - in favour of Lord Gormanston. An attack on the status of the barony of Slane, from which the family took its title, was therefore likely to cause maximum offence. ${ }^{17}$

The timing of Christopher Fleming's petition undoubtedly reflected other personal concerns. There was, of course, the continual pressure being exerted on Fleming lands in Meath by the Irish. Attacks in 1423 and 1427 had caused considerable damage. However, additional incursions in 1430 and 1434 can only have served to increase Fleming resentment at an ineffectual Dublin administration. On succeeding to his estates, Christopher Fleming quickly set about their reorganisation in 1437. The original charter, granting the manor of Slane to Baldwin Fleming in May 1333, stated that it was held in tail male. Christopher Fleming appears to have been seeking consistency on both sides of the Irish Sea. Constant harassment by the Irish Exchequer was therefore a source of some irritation to Fleming. He obviously felt that he was unlikely to secure a favourable decision in Ireland ${ }^{18} \mathrm{He}$ therefore brought his complaint to England, where the Crown exercised an appellate jurisdiction over Irish affairs. For Christopher Fleming, England was not some far-off land. Nor was the king a remote figure. Interestingly, no official search of Irish Exchequer records was apparently made. No mention of this case is made amongst the surviving records of the King's Council in England. Nevertheless, the minority Council of Henry VI in England clearly did hear the complaint, and agreed with Christopher Fleming's argument that Slane was not held directly from the Crown. This would appear to reflect the broader policy of the English government to mitigate the worst excesses of corruption and inefficiency pervading the Irish administration. It was fortunate for Fleming that Irish affairs were high on the political agenda in England at that time. Thomas Chace, the chancellor of Ireland, had made some non-partisan appointments to the Irish Council in the winter of 1437-8, and these were then discussed by the Council in England in February 1438. ${ }^{19}$ A privy-seal writ was subsequently sent from England

17 Gormanston reg., pp xviii, 2. The exact dates are unknown, but the barony had come into the Flemings' possession by 1372: Otway-Ruthven, 'The partition of the De Verdon lands', p. 417.

18 There had been moves in the 1428-9 Irish parliament to force those who took allegations of corruption to the Council in England to find surety to prosecute them, in which the charges would be sent back to Ireland to be examined in the next parliament or Great Council, which would then report to the king: Stat. Ire., Hen. VI, pp 10-25.

19 Treasury of receipt: Council and privy seal records, July-Aug., 17, Hen. VI (T.N.A. P.R.O., E28/62/28); Proc. Privy Council, 15-21, Henry VI, 5, pp 89-90; Cal. pat. rolls, $1436-41$, pp 132, 184. 
to Ireland ordering the chancellor and treasurer to amend their records in Fleming's favour. After almost four decades in dispute with the Anglo-Irish administration, Christopher Fleming's decision to bring his case to England seemed to have been vindicated, and whilst the barony of Slane was still subject to military threat, its legal status had been successfully defended, and family honour satisfied. ${ }^{20}$

\author{
MALCOLM MERCER \\ Canterbury Cathedral Archives
}

${ }^{20}$ Although this episode seemed to be resolved, the story of the tenure of the barony of Slane does not quite end here. On the statute rolls for Ireland in 1459, the inquisition post mortem of Christopher Fleming found that the manor of Slane was held from the king by service of one penny. The same statement of tenure was recorded when Thomas Fleming was given livery of the Fleming lands in 1470: see Stat. Ire., Hen. VI, p. 611; Stat. Ire., 1-12 $E d w . I V$, p. 669 . The reasons for this will form the subject of a further article. 


\section{T.N.A. P.R.O., C103/18}

To ye kyng oure souverain lord. Besechethe mekely your liege man Cristofre Flemmyng off youre lande and lordesshippe of Irelande knyght yat where oon Robert de Bosco, Henry Russelle late weren seisid of the manoire of Slane withe alle his appurtenances withynne your saide londe and lordeshippe yn her demene as in fee which manoir yan was holden of Nicholas Houthe, Robert Wakeman and Richard Eustace as of a thride parte of ye fourthe parte of ye manoire of Dyueleke by knyghtes services; whoos astate ye saide Cristofre hathe in ye seide thrid parte of ye seide fourthe part of ye seide manoir of Dyueleke ye whiche manoir of Dyueleke is and hathe be holden of you and your progenitoures kynges of Englande and lordes of the seide lande and lordeshippe of Irelande by the same services alle tymes sithen ye conquest of the saide lande and lordeshippe of Irelande; ye whiche Robert de Bosco and Henri Russelle yaven and graunten ye saide manoir of Slane withe alle his appurtenaunces to oon Symond Flemmyng son to Bawdewyn Flemmyng knyght and to his heirs masles of his body be goten by vertu of the whiche yeft and graunte ye said Symond was seised in his demesne as in fee taile and of yat estate died in ye seid manoir y seised after whoos deth Thomas Flemmyng as son and heire male to ye said Symond entred in to ye said manoir and therof was y seised in his demene as in fee taile by vertue of ye yeft abouesaid and so beyng ye said Thomas y seised of ye same manoir of Slane oon William Tynbeghe ${ }^{21}$ now dede, yat is to seye on the moneday next afor the fest of ye purificacioun of oure blessed lady in ye viii yere of the regne of the right noble prynce Kyng Henry the Fift youre fadre; the said William yan being Under Tresourer to your said noble fader of ye land and lordeshippe of Irelande for grete malice and evilwille yat ye said William yan yer had to the said Thomas at Dyvelyn now your citee in a place now called your Receit commaunded oon Johan Coryngham ${ }^{22}$ nowe on lyve and yan ther beyng his clerk to entre and write in a boke yer yat is and hath be called ye Whiteboke ${ }^{23}$ of yes wordes Thomas Flemmyng Baro de Slane pro Slane que tenetur de domino Rege per septem servicia, the which boke is ther yn your Tresoury and hath be at alle tymes sithe the conquest of the said lande ye whiche boke is ther so hye and so grete of recorde that no man schalle ther be received ne amitted to travers ne say the contrarie of no worde ne matiere founde writt in ye said boke sithen the whiche wordes so of malice in to ye said boke written and entred the said manoir hath be taken a yenst alle conscience and trouthe to be hold of you and of your said noble fadre by knyght services immediate; and the said Thomas had issue your said nowe besecher and of suche estate died seised in ye said manoir of Slane after whoos deth the said manoir descended to your said besecher as son and heir masle to the said Thomas by vertue of the whiche descent your seid besecher is y seised in the seid manoir of Slane in his demene as in fee taile; and sithen the dethe of ye said Thomas the said Cristofre hathe be gretely vexed by your officers and ministres

21 Treasurer of Ireland from 1421 onwards: Connolly (ed.), Irish Exchequer payments, pp 552, 554 .

${ }_{22}$ Later clerk of the works of Dublin Castle: see Connolly (ed.), Irish Exchequer payments, pp 549, 552, 554, 563, 568, 573, 574, 575, 577, 578, 579, 580, 581, 582.

23 Treasurers' accounts were apparently audited in Ireland between 1399 and 1420 . Information relating to accounts up to 1406 appears in extracts from the White Book of the Irish Exchequer (B.L., Add. MS, 4783; Connolly (ed.), Irish Exchequer payments, p. 548 n. 4). 
and yit is fro day to day for xiiii li claymed ther by your officers and ministres yn your name for escuage supposed to be to you deue of the said Cristofre by cause of the said writyng yn the said Whiteboke a yenst trouthe and alle conscience in ye manere and fourme abouesaid to ye grete destruccioun and disheritaunce of your seid besecher and his heires wythout your right habundaunte grace and socour in yis cas please it to your hieghe and reialle maiestre to considere thes matieres abouesaid and of your especiale grace to send this symple peticioun withe youre gracieux lettres of privie sealle to your Chaunceller and Tresorer of youre said lande and lordeshippe of Ireland or to here deputes yer commaundyng hem by your seid gracieux lettres to truely examine ye matieres contiegned in yis seid peticioun afor hem yer aftyr her discrecioun or to enquere there by treue laufulle and indifferent men of the said land and lordshippe of the said matieres commaundyng hem forthermore by youre said gracieux lettres that if the matiere contiegned in this said peticion for the partie of the said Cristofre be afor hem there founde treue; that than your said Chaunceller or his said depute to discharge by writing under your grete seal yer the said Cristofre and his seid heires of the said xiiii li and for the said tenure of ye saide manoir of Slane so of you supposed immediately be holden; and that ye forsaid wordes that is to say Thomas Flemmyng Baro de Slane pro Slane que tenetur de domino Rege per septem servicia maien by your said Chanceller and tresourer or her deputees be yen yer drawen out of the said Whiteboke so yat ye seid Cristofre and his said heires be nevere hurt ne troublet yerby hereaftyr; noghte withstandyng that ther ys no expresse mencioun made yn this said peticioun of any mysprisioun or undue lyvereyes of the said manoir of Slane by any of ye auncestres of your said besecher out of the handes of any of your right worthy and noble auncestres or progenitours afor this tyme had or sued ayenst ye fourme and ye effecte of the saide taile; and that also your said Chaunceller or his said depute make and graunte to and for the said Cristofre covenable and necessary writtes in ye said case for to discharge the said Cristofre and his said heires of the forsaid xiiii li; and that for the love of almighty god and in way of charite. 


\section{Transliteration}

To the King our sovereign lord. Beseeching meekly your liege man Christopher Fleming of your land and lordship of Ireland, knight, that where one Robert de Bosco, Henry Russell late were seised of the manor of Slane with all its appurtenances within your said land and lordship in their demesne as in fee, which manor then was held of Nicholas Houth, Robert Wakeman and Robert Eustace as of a third part of the fourth part of the manor of Duleek by knight's service, whose estate the said Christopher has in the said third part of the said fourth part of the said manor of Duleek; the which manor of Duleek is and has been held of you and your progenitors, kings of England and lords of the said lordship of Ireland by the same services all times since the conquest of the said land and lordship of Ireland; the which Robert de Bosco and Henry Russell gave and granted the said manor of Slane with all its appurtenances to one Simon Fleming, son of Baldwin Fleming, and to his heirs male of his body begotten, by virtue of the which gift and grant the said Simon was seised in his demesne as in fee tail, and of that estate died in the said manor then seised; after whose death Thomas Fleming, as son and heir male to the said Simon entered in the said manor and thereof was then seised in his demesne as in fee tail by virtue of the gift abovesaid; and so being, the said Thomas then seised of the same manor of Slane, one William Tynbergh, now dead, that is to say on the Monday next before the Feast of the Purification of our Blessed Lady in the viii year of the reign of the right noble prince, King Henry the Fifth, your father, the said William, then being Under Treasurer to your said noble father of the land and lordship of Ireland, for great malice and evil will that the said William then had to the said Thomas at Dublin, nor your city in a place now called your Receipt, commanded one John Coryngham, now alive, and then being his clerk, to enter and write in a book there, that is and has been called the White Book, of these words, Thomas Flemmyng Baro de Slane pro Slane que tenetur de domino Rege per septem servicia, the which book is there in your Treasury and has been at all times since the conquest of the said land, the which book is there so high and so great of record that no man shall there be received nor admitted to traverse nor say the contrary of no word nor matter found written in the said book; since the which words so of malice into the said book written and entered the said manor has been taken against all conscience and truth to be held of you and your said noble father by knight service immediate; and the said Thomas had issue, your said now beseecher, and of such estate died seised in the said manor of Slane, after whose death the said manor descended to your said beseecher as son and heir male to the said Thomas, by virtue of the which descent your said beseecher is then seised in the said manor of Slane in his demesne as in fee tail; and since the death of the said Thomas the said Christopher has been greatly vexed by your officers and ministers, and it is from day to day for $£ 14$ claimed there by your officers and ministers in your name for scutage supposed to be to you due of the said Christopher because of the said writing in the said White Book against truth and all conscience in the manner and form abovesaid to the great destruction and disinheritance of your said beseecher and his heirs without your right abundant grace and succour in this case; please it your high and royal master to consider these matters abovesaid, and of your special grace to send this simple petition with your gracious letters of privy seal to your Chancellor and Treasurer of your said land and lordship of Ireland or her deputies there, commanding them by your 
gracious letters to truly examine the matters after their discretion or to enquire there by two lawful and indifferent men of the said land and lordship of the said matters, commanding them furthermore by your said gracious letters that if the matter contained in this said petition for the part of the said Christopher before them found true, that then your said Chancellor or his said deputy to discharge by writing under your great seal there the said Christopher and his said heirs, of the said $£ 14$ and for the said tenure of the said manor of Slane, so of you supposed immediately [to] be held; and that the aforesaid words, that is to say Thomas Flemmyng Baro de Slane que tenet de domino Rege per septem servicia may be your said Chancellor and Treasurer or their deputies be then there drawn out of the said White Book so that the said Christopher and his said heirs be never hurt nor troubled thereby hereafter; notwithstanding that there is no express mention made in this said petition of any misprision or undue liveries of the said manor of Slane by any of the ancestors of your said beseecher out of the hands of any of your right worthy and noble ancestors or progenitors before this time had or sued against the form and effect of the said tail; and that also your said Chancellor or his said deputy make and grant to and for the said Christopher and his said heirs of the aforesaid $£ 14$; and that for the loss of almighty god and in way of charity. 